\title{
Extracted Neam Leaf (Azadirachta indica A. Juss) to Control Alternaria Porri Ell. Cif. In Shallot Plants (Allium ascalonicum L.)
}

\author{
Yenny Muliani ${ }^{1 *}$, Elly Roosma Ria ${ }^{2}$, Tien Turmuktini' ${ }^{2}$, Endang Kantikowati ${ }^{3}$ and S. Wawan $^{1}$ \\ Date Received: $18^{\text {th }}$ December 2019 / Date Accepted: $28^{\text {th }}$ January 2020
}

\begin{abstract}
Purpose: To test the effectiveness of neem leaves in suppressing the development of Alternaria porri causing purple blotch and to provide information about the use of neem leaves to control these purple blotch on shallots

Research Method: The research was conducted at the Lembang Botanical Research Institute (BALITSA) at altitude $+1,250$ meters above sea level (masl) with average temperatures ranging from 19-24 OC, humidity ranging from 39-90\% and average rainfall of 2,207, $5 \mathrm{~mm} /$ year. The trial period starts from the beginning of November 2018 until January 2019. The study was conducted in the field using an experimental method with a randomized block design (RBD) consisting of 6 treatments and 4 replications. These treatments are Application of

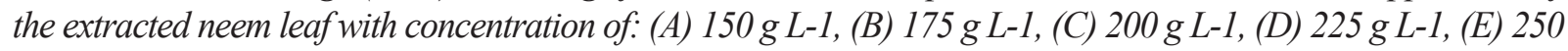
$g$ L-1, and (F) Control / without application.

Experimental data analysis was carried out based on a linear model for the Randomized Block Design $(R B D)$. The obtained data were statistically analyzed by variance analysis with the $F$ test on variables. The F test results showed significant differences. To differentiate the average of each conducted treatment, further tests with Duncan's multiple range method on real level of 5\% is tested.
\end{abstract}

Findings : Neem leaves can act as a botanical pesticide that is easy to make and easy to apply for farmers. The extracted neem leaf application with a concentration of $225 \mathrm{~g} \mathrm{L-1}$ is the best concentration and is able to suppress the development of Alternaria porri causing purple spots on shallot plants.

Limitations : The secondary metabolite content of the mimba plant is found in parts of the seeds, but in the west java area the neem tree does not produce seeds, so in this study only uses the leaves.

Value : The use of botanical pesticide derived from neem leaves is able to reduce the use of synthetic pesticide, so as to reduce the effects of residual causes of environmental pollution.

Keywords: Azadirachta indica A. Juss, Alternaria Porri Ell. Cif., Allium ascalonicum L.

\section{INTRODUCTION}

Shallot production is one of the sources of income and provides employment opportunities for the community and significantly contributes to economic development in the regions that produce it (Direktorat Jendral Hortikultura, 2018). Shallots are often used as a food flavoring and contain nutrients as well as enzymes that are beneficial for therapy and are able to improve and maintain the health of the human body (Dewantoro, 2012; Jessie Szalayantoro, 2017).

This plant also contains active chemical compounds, such as sulfur compounds that are useful as herbal medicines to cure diseases, such as colds, constipation, coughing, fever,

\footnotetext{
1* Department of Agricultural, Faculty of Agriculture, Universitas Islam Nusantara, Bandung-Indonesia. yennymuliani62@gmail.com

2 Department of Agricultural, Faculty of Agriculture, Universitas Winaya Mukti, Indonesia.

3 Faculty of Agriculture, Universitas Bale Bandung, Jalan RAA Wiranatakusumah 7 Baleendah Bandung Regency 40258

(D) ORCID http://orcid.org/0000-0001-6541-5440
} 
diarrhea, cancer, hypertension, cholesterol, and even diabetes (Aryanta, 2019).

The community's need of the shallots from year to year has increased by 5.74 percent (Ministry of Agriculture, 2015). The average consumption of shallots per capita for 2012-2019 is around 2.39 / capita / year (Bapenas, 2016). Red shallot consumption has increased quite high, especially ahead of the feast, which ranges from 10-20\% (Direktorat Jendral Hortikultura, 2018). Shallot productivity has decreased and this is due to the attack of plant-disturbing organisms (OPT), such as purple spot disease caused by Alternaria porri Ell. Cif (Kareem, Murthy, Nadaf, \& Waseem, 2012). Purple spotting is a major disease in shallot plants throughout the world. This disease is also widespread in shallot growing areas in Indonesia, including West Java, Central Java, East Java, West Nusa Tenggara, East Nusa Tenggara, and Irian Jaya (Bapenas, 2016).

Loss of productivity due to purple spots on shallots reaches $50 \%$ to $57 \%$ can even cause crop failure (Gunaeni, 2015a)(Gunaeni, 2015b). Based onthe results of invitro tests show that purple spotting has a speed of developing so fast that is equal to $14.67 \%$ (Hersanti, Sudarajat, \& Damayanti, 2019). The attack of this disease occurs generally in the rainy season, marked by whitish spots, over time the oval-shaped purple, grayish and black flour (Adnyana, 2012) The use of synthetic pesticides to control this disease will have negative impacts such as can cause resistance, resurgence, killing natural enemies, environmental pollution, and dangering human health (Baihaki \& Sudrajat, 1977; Y et al., 2015) therefore, an alternative control that takes into consideration of ecological and technological aspects by utilizing a variety of compatible control components in a coordinated unity of control systems that are environmentally friendly and sustainable (Laba I Wayan, 2010).

At present, pesticides which have been derived from plants or are popularly known as plantbased pesticides. The use of natural ingredients as controlling pests and diseases is still not widely used by farmers. The prospect of developing botanical pesticides in Indonesia is quite good because it is supported by abundant natural resources. Some of the advantages of botanical pesticides include biodegradability and leave no residue, relatively safe for humans (Erdi, Jailani, \& Sartika, 2017), easily obtained, easily accessible and easily mixed by farmers (Sudarmo \& Mulyaningsih, 2014). This is in line with the government's program in terms of plant protection in the application of integrated pest control techniques in accordance with Presidential Instruction No.3 of 1998, where it is necessary to apply alternatives in pest control developed such as plant-based insecticides, which are natural products that are environmentally friendly and leave no residues for plants and the environment.

One type of botanical pesticide that is widely known to the public is derived from the neem tree (Azadirachta indica A. Juss). This plant can be used as an insecticide, bactericide, fungicide, acariside, nematicide, and virisida. The active compounds contained mainly in the seeds are azadirachtin, meliantriol, salannin, and nimbin compounds (Andy, 2013). Chloroform extract contained in neem can inhibit the development of Fusarium sp. with a concentration of 50 ppm a large obstacle of $9.5 \mathrm{~mm}, 70 \mathrm{ppm}$ a large obstacle of 9.75, and 100 ppm a large obstacle of 18.5 (Wahyuni, Puspawati, \& Arista, 2016). The use of neem plants as a botanical pesticide to control Alternaria porri which causes purple spot disease in shallot plants in vivo has not been done much, therefore, it is necessary to do experiment to find out the right concentration of the extract neem leaf in controlling purple spot disease on shallot plants.

\section{MATERIALS AND METHODS}

The research was conducted at the Lembang Botanical Research Institute (BALITSA) at altitude $+1,250$ meters above sea level (masl) with average temperatures ranging from 19$240 \mathrm{C}$, humidity ranging from 39-90\% and average rainfall of 2,207, $5 \mathrm{~mm} /$ year. The trial period starts from the beginning of November 2018 until January 2019. Material used: Shallot plant seeds, neem leaves, soil, organic fertilizer, and NPK fertilizer. The used tools: Hoes, 
mulch, rulers, blenders, test tubes, analytical scales, buckets and semi-automatic sprayers. The study was conducted in the field using an experimental method with a Randomized Block Design (RBD) consisting of 6 treatments and 4 replications. These treatments are; Application of the extracted neem leaf with concentration of: (A) $150 \mathrm{~g} \mathrm{~L}^{-1}$, (B) $175 \mathrm{~g} \mathrm{~L}^{-1}$, (C) $200 \mathrm{~g} \mathrm{~L}^{-1}$, (D) $225 \mathrm{~g} \mathrm{~L}^{-1}$, (E) $250 \mathrm{~g} \mathrm{~L}^{-1}$, and (F) Control / without application.

Experimental data analysis was carried out based on a linear model for the Randomized Block Design (RBD). The obtained data were statistically analyzed by variance analysis with the $\mathrm{F}$ test on variables. The $\mathrm{F}$ test results showed significant differences. To differentiate the average of each conducted treatment, further tests with Duncan's multiple range method on real level of $5 \%$ is tested. Numbers followed by the same letter in the same column indicate no significant difference.

Using formula: LSR $=$ SSR $x$ Sx where :

LSR : Least Significant Ranges,

SSR : Studentized Significant Ranges,

$\mathrm{Sx}:$ Average standard error $=\sqrt{ }((\mathrm{KT}$ Galat)/r)
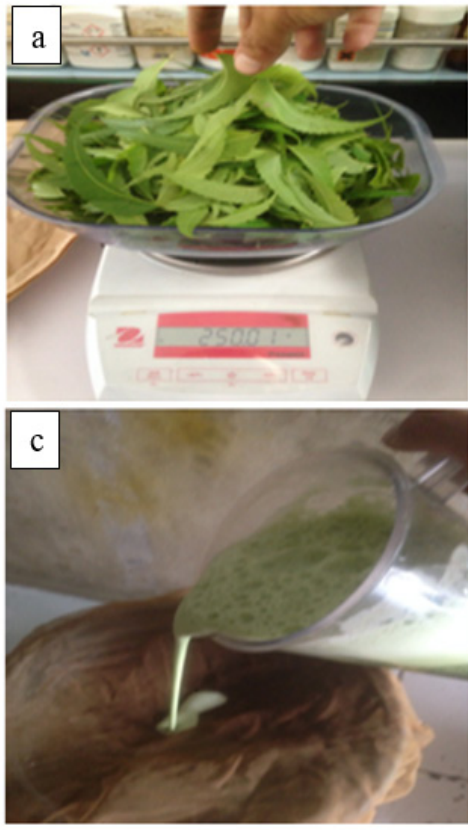

In summary the activities flow can be seen as in Figure 01.

The land is cultivated and the soil mixed with fertilizer and made beds with a width of 110 $\mathrm{cm}$ and a length of $450 \mathrm{~cm}$. The used bulbs were the bulbous shallot varieties of Batu ijo belonging to the Lembang Botanical Crops Research Institute. Planting seeds is done by making a planting hole covered with mulch with a spacing of $15 \times 15 \mathrm{~cm}$, then the seed is buried in the ground. Observations were made on the intensity of the Alternaria porri attack causing purple spots on the shallot plants. The amount of damage caused by a disease attack based on a scale (score) according to [17], is calculated by :

$$
I=\frac{\sum \text { (nixvi) }}{N \times Z} \times 100 \%
$$

where. $I$ is Intensity of attacks; $n_{i}$ is Number of plants or parts of the sample plant with scale of damage symptoms; $v_{i}=$ Damage scale value; $\mathrm{N}=$ Number of plants or plant parts, $\mathrm{Z}=$ The highest scale damage value. The attack category value (v) is based on the following attack area : $0=$ No damage at all (healthy), $1=$ Area of damage $>0, \leq 20 \%, 2=$ Area of damage $>20, \leq$ $40 \%, 3=$ Area of damage $>40, \leq 60 \%, 4=$ Area of damage $>60, \leq 80 \%, 5=$ Area of damage $>$ $80, \leq 100 \%$
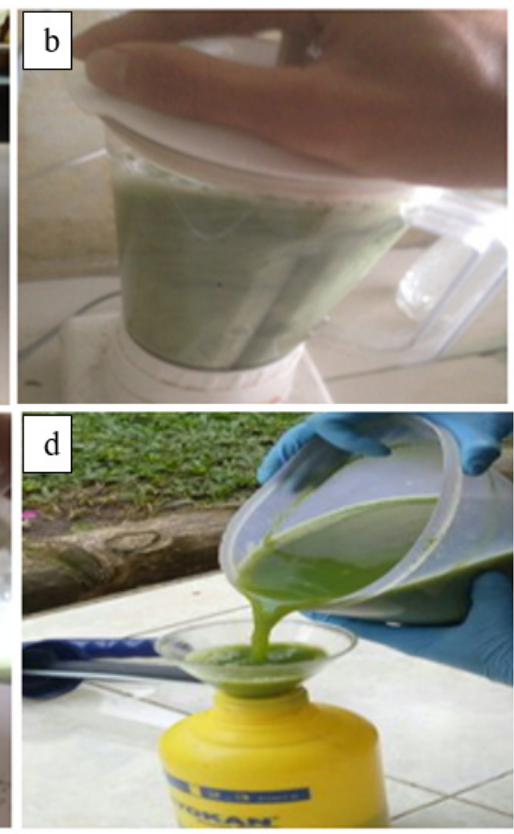

Figure 01: (a). It weighs 250 g.neem leaf, (b). Add $70 \% 10 \mathrm{ml}$ alcohol as a solvent for active ingredients and detergents as much as 1 gram as an adhesive and then blended, (c). The results are then filtered, (d). Neem extract is ready to be applied. 


\section{RESULTS AND DISCUSSIONS}

Observation of the purple spots intensity on shallot (Allium ascalonicum L.) caused by Alternaria porri was conducted before the treatment application. Application was started after the shallot plants were aged 3 WAP, 4 WAP, 5 WAP, 6 WAP, 7 WAP, and 8 WAP. The observations results of the purple spot disease intensity are presented in Table 01 .

The average intensity of purple patches caused by A. porri on shallots on observations 3 weeks after planting (3 WAP), shows that all plants have been attacked by purple spots, with the intensity of attacks on all plants not significantly different. The intensity of purple spotting caused by $A$. porri in shallot plants (Allium ascalonicum L.) can be seen in Figure 02.

At 4 WAP there was an increase in the intensity of purple spotting attacks on all shallot plants, this was due to the factors supporting the growth of the disease due to virulent pathogens, susceptible hosts and a supportive environment. At 5 WAP, 6 WAP, 7 WAP, and 8 WAP showed that the control treatment was significantly different from all treatments. The high intensity of the disease in the control treatment, compared with other treatments due to the presence of virulent pathogens that attack but the application is not made of the extract neem leaf, so there is no emphasis on the disease attack. As the age of the shallot plants increases, more and more saplings are formed, which results in conditions around the plant becoming moist and growing better (Winarto \& Chairuman, 2011). This is in line with the statement of (Sastrahidayat, 2011) that the highest attack of purple spots occurs on old leaves and at the time of tuber formation until harvest.

The lowest of disease intensity occurred in the treatment of the extracted neem leaf with concentration of $250 \mathrm{~g} \mathrm{~L}^{-1}$. The treatment of the extracted neem leaf about $250 \mathrm{~g} \mathrm{~L}^{-1}$ was highest in suppressing the development of $A$. porri disease, but not significantly different from the concentration of $225 \mathrm{~g} \mathrm{~L}^{-1}$. This is consistent with the research results of (Ariyanti \& Jahuddin, R. Yunus, 2012) which conducted in vitro states that the use of the extracts neem leaf with higher concentrations up to a certain point can cause fungi tocsic, where the extracted neem leaf will poison and stop the growth.

Table 01: $\quad$ Results of Analysis of Average Purple Spots Intensity in Shallot (Allium ascalonicum L.) Plants

\begin{tabular}{ccccccc}
\hline \multirow{2}{*}{ Treatment } & \multicolumn{6}{c}{ Mean Intensity of Alternaria porri Disease } \\
\cline { 2 - 7 } & $3 \mathrm{WAP}$ & $4 \mathrm{WAP}$ & $5 \mathrm{WAP}$ & $6 \mathrm{WAP}$ & $7 \mathrm{WAP}$ & $8 \mathrm{WAP}$ \\
\hline $\mathrm{A}$ & $4,45 \mathrm{a}$ & $23 \mathrm{~b}$ & $26,5 \mathrm{~b}$ & $29 \mathrm{~b}$ & $30 \mathrm{~b}$ & $35 \mathrm{~b}$ \\
$\mathrm{~B}$ & $4,58 \mathrm{a}$ & $22 \mathrm{~b}$ & $25 \mathrm{bc}$ & $26 \mathrm{bc}$ & $27,5 \mathrm{bc}$ & $32 \mathrm{bc}$ \\
$\mathrm{C}$ & $4,52 \mathrm{a}$ & $21,5 \mathrm{~b}$ & $23 \mathrm{c}$ & $24 \mathrm{~cd}$ & $25 \mathrm{~cd}$ & $29 \mathrm{~cd}$ \\
$\mathrm{D}$ & $4,63 \mathrm{a}$ & $21 \mathrm{~b}$ & $22,5 \mathrm{c}$ & $21 \mathrm{de}$ & $22,5 \mathrm{de}$ & $25 \mathrm{de}$ \\
$\mathrm{E}$ & $4,36 \mathrm{a}$ & $20,5 \mathrm{~b}$ & $22 \mathrm{c}$ & $20 \mathrm{e}$ & $22 \mathrm{e}$ & $23 \mathrm{e}$ \\
F & $4,65 \mathrm{a}$ & $29 \mathrm{a}$ & $32 \mathrm{a}$ & $34,5 \mathrm{a}$ & $40 \mathrm{a}$ & $45 \mathrm{a}$ \\
\hline
\end{tabular}

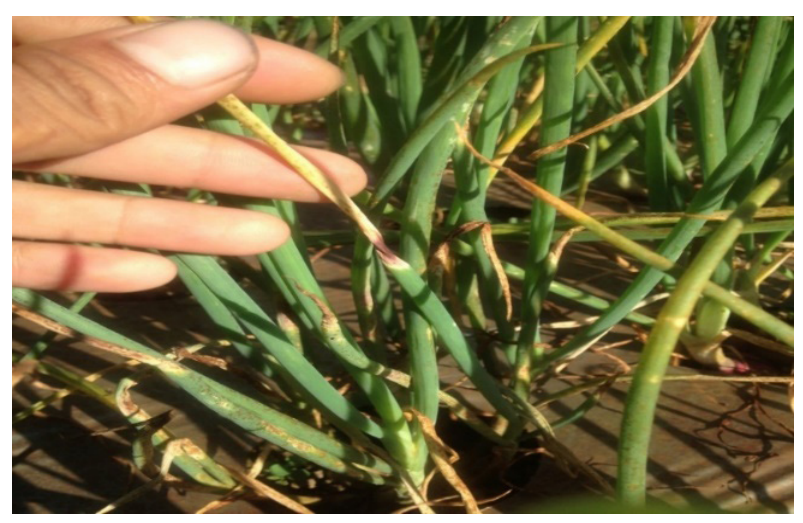

Source: Personal Collection

Figure 02 Symptoms of Purple Spots 


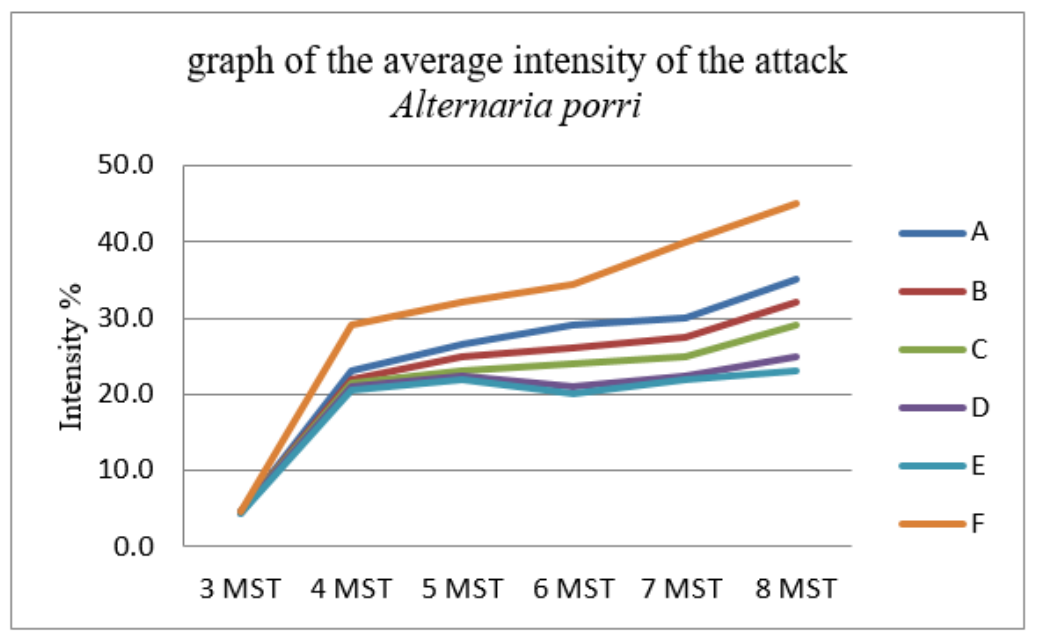

Figure 03: Graph of Average Intensity of Spotting Disease in Shallots (Allium ascalonicum L.)

From Figure 03 it can be assumed that with the intensity of purple spotting attacks on shallot plants that are not treated with the extracted neem leaf, their development continues to increase even reaching around 48\%. The intensity of the disease in shallot plants treated with the extracted neem leaf is able to control A. porri up to $50 \%$. It can be interpreted that neem leaves have the potential as plant-based pesticides which are able to control A.porri causing purple spots on shallot plants.

\section{CONCLUSIONS}

The extracted neem leaf ( $A$. indica A. Juss.) at a concentration of $225 \mathrm{~g} \mathrm{~L}^{-1}$ is able to suppress the intensity of $A$. porri's attack that causes purple spotting on shallot (A. ascalonicum L.) plants around $50 \%$.

\section{Data Availability Statement}

The datasets generated during and/or analysed during the current study are available from the corresponding author on reasonable request.

\section{ACKNOWLEDGMENT}

The author would like to thank Mrs. Eti Henni from the Botanical Crops Research Institute, who provided the research facility.

\section{REFERENCES}

Adnyana. (2012). Efficacy of Tropical Plant Essential Oil Pesticides on the Mortality of Gempinis Fur caterpillars. Journal of Tropical Agroecology, 1(1), 1-11.

Andy. (2013). Examination of Neem Leaf Extract (Azadirachta indica) and Kluwek Leaf Extract (Pangium edule) on the death of gray caterpillar (Spodoptera sp.). Retrieved October 2, 2019, from http://onesearch.id.record/IOS2763.5491.9

Ariyanti, E. L., \& Jahuddin, R. Yunus, M. (2012). The potential of neem leaf extract (Azadirachta indica) as a biofungicide of strawberry rot (Colletotrichum fragariae brooks). In-vitro. Journal Agrooteknos, 2(3), 88-93.

Aryanta, I. W. R. (2019). Shallots And Their Health Benefits. Widiya Kesehatan, 1(1), 25-35. https://doi.org/10.32795/widyakesehatan.v1i1.280

Baihaki, A., \& Sudrajat, M. (1977). Design and Analysis of Experiments. Statistics Section. Bandung: Faculty of Agriculture. Padjadjaran University. 
Bapenas. (2016). Horticultural Sub Sector Agricultural Commodities. Center for Agricultural Data and Information Systems Ministry of Agriculture. Retrieved August 2, 2019, from

Dewantoro. (2012). Red Onion Import Partner Farmers Right on Target.

Direktorat Jendral Hortikultura. (2018). Performance Report of the Directorate General of Horticulture TA. 2017. Retrieved August 3, 2019, from http:/hortikultura. pertanian.go.ig

Erdi, S., Jailani, \& Sartika, D. M. (2017). Effect of Neem Leaf Extract (Azedirachta indica) on Mortality of Leaf Caterpillars (Plutella xylostella) on Shallot Plants (Allium ascalonicum L). Variation, $9(1)$.

Gunaeni. (2015a). Physical and Mechanical Control of Pests and Diseases in the Production of Shallots (Allium ascolonicum L.). Agrin Journal, 19(1), 37-57.

Gunaeni, N. (2015b). Physical and Mechanical Control of Pests and Diseases in the Production of Shallots (Allium ascolonicum L.). Agrin Journal, 19(1), 37-57.

Hersanti, Sudarajat, \& Damayanti, A. (2019). The ability of Bacillus subtilis and Lysinibacillus sp. In Nano Silica And Carbon Fiber For For. Inducing Shallot Against Purple Spots (Alternaria porri (Ell.) Cif). Jurnal Agrikultura, 3(1), 8-16. https://doi.org/https://doi.org/10.24198/ agrikultura.v30i1.22698

Jessie Szalayantoro. (2017). Onions: Health Benefits, Health Risks \& Nutrition Facts.

Kareem, M. A., Murthy, K. V. M. ., Nadaf, H. A., \& Waseem, M. . (2012). Effect of temperature, relative humidity and light on lesion length due to Alternaria porri in inion. Asian J Enviro Sci, 7, 47-49.

Laba I Wayan. (2010). Empirical Analysis of the Use of Insecticides Towards Sustainable Agriculture. In Research Professor's Oration in Bogor, Agricultural Innovation Development (Vol. 3, pp. 120-137).

Ministry of Agriculture. (2015). Agricultural commodities in the horticultural sub-sector. Shallots available at. Retrieved September 29, 2018, from http: //epublikasi.setjen .pertanian.go.id/ epubli kasioutlook / 2015 / horticulture / Outlook\%25 20Onions\%25 20Red\%25 202015 / files / assets / common / dowloads / Outlook

Sastrahidayat, I. R. (2011). Phytopathology (plant disease). University of Brawijaya Press.

Sudarmo, S., \& Mulyaningsih, S. (2014). Easy to Make Vegetable Pesticides (1st ed.).

Wahyuni, S., Puspawati, N. M., \& Arista, N. P. R. E. (2016). Isolation and Identification of AntiFungal Active Compounds from Neem Leaves (Azadiractha indica A. Juss) as Fusarium sp Mushroom Control in Dragon Fruit Plants (Hylocereus sp). Retrieved from http://ojs.unud. ac.id

Winarto, L., \& Chairuman, N. (2011). North Sumatra Agricultural Technology Study Center. North Sumatra Agricultural Technology Study Center.

Y, S., IM, S., TP, P., DN, S., P, L., \& Sutoro. (2015). Antibacterial Activity of 11UJ Bacillus cereus Against Rhizoctonia solani and Pyricularia oryzae. Indonesian Journal of Phytopathology, 11(2), 35-42. 